\title{
The Effect of Rapid Heating and Fast Cooling on the Transformation Behavior and Mechanical Properties of an Advanced High Strength Steel (AHSS)
}

\author{
Juan Pablo Pedraza ${ }^{1}$, Rafael Landa-Mejia ${ }^{2}$, Omar García-Rincon ${ }^{1}$ and C. Isaac Garcia ${ }^{2, *}$ \\ 1 Ternium-Mexico, 66450 San Nicolas de los Garza, Nuevo Leon, Mexico; JPEDRAZA@ternium.com.mx (J.P.P.); \\ ogarciar@ternium.com.mx (O.G.-R.) \\ 2 Ferrous Physical Metallurgy Group, Mechanical Engineering and Materials Science Department, \\ University of Pittsburgh, Pittsburgh, PA 15261, USA; ral76@pitt.edu \\ * Correspondence: cigarcia@pitt.edu
}

Received: 11 March 2019; Accepted: 7 May 2019; Published: 10 May 2019

\begin{abstract}
The major goal of this work was to study the effect of rapid heating and fast cooling on the transformation behavior of 22MnB5 steel. The effect of the initial microstructure (ferrite + pearlite or fully spheroidized) on the transformation behavior of austenite (during intercritical and supercritical annealing) in terms of heating rates $\left(2.5,30 \& 200{ }^{\circ} \mathrm{C} / \mathrm{s}\right)$ and fast cooling, i.e., $300{ }^{\circ} \mathrm{C} / \mathrm{s}$ rate, were studied. As expected, the kinetics of austenite nucleation and growth were strongly related to the heating rates. Similarly, the carbon content of the austenite was higher at lower intercritical annealing temperatures, particularly when slower heating rates were used. The supercritical temperatures used in this study were similar to those used during commercial hot stamping operations, i.e., 845 and $895^{\circ} \mathrm{C}$, respectively, followed by a fast cooling rate. The prior austenite grain size (PAGS) was not strongly influenced by the nature of the initial microstructure, heating rate, reheating temperatures ( 845 or $895^{\circ} \mathrm{C}$ ), at $30 \mathrm{~s}$ holding time. The decomposition of austenite using fast cooling rates was examined. The results showed that $100 \%$ martensite was not obtained. The observed low temperature transformation products consisted of mixtures of martensite-bainite plus undissolved $\mathrm{Fe}_{3} \mathrm{C}$ carbides and small amounts of martensite-austenite (M-A). At higher supercritical temperatures, i.e., $1000{ }^{\circ} \mathrm{C}$ and $1050{ }^{\circ} \mathrm{C}$, the final microstructure showed an increase in the volume fraction of martensite and a decrease in the volume fraction of bainite. The $\mathrm{Fe}_{3} \mathrm{C}$ and the M-A microconstituent were not observed. The best combination of tensile properties was obtained on samples reheated in the lower temperature range $\left(845\right.$ to $\left.895^{\circ} \mathrm{C}\right)$. Interestingly, when the samples where reheated at the higher temperature range $\left(1000\right.$ to $1050^{\circ} \mathrm{C}$ ) and fast cooled, the results of the mechanical properties did not exhibit significantly higher strength levels independent of heating rate or initial microstructural condition. This can be attributed to the change in the microstructural balance \%martensite+\%bainite as the reheating temperature increases. The results of this study are presented and discussed.
\end{abstract}

Keywords: EBSD-IQ; fast heating rate; formation of austenite; initial microstructure; PAGS; transformation behavior; tensile properties

\section{Introduction}

The continuous demand of using AHSS and UHSS steels, particularly Press Hardenable Steels (PHS), during hot stamping operations requires a systematic and fundamental understanding of the physical metallurgy of these steels. According to recent report on the use of AHSS and UHSS in North America, light weight vehicles are predicted to increase from the current 332 pounds per vehicle to 483 pounds by the year 2025 [1]. To achieve the desired performance of AHSS many studies are being conducted by universities and steel companies around the world. For example, Figure 1 shows 
the different pathways currently being studied to increase the strength and ductility of AHSS [1]. In addition, this figure also presents actual coating data for AHSS GEN 1 and 3 steels. It seems that the major research trends to increase the performance of AHSS strength-ductility are strongly related with the ability to control composition, microstructure and dislocation motion.

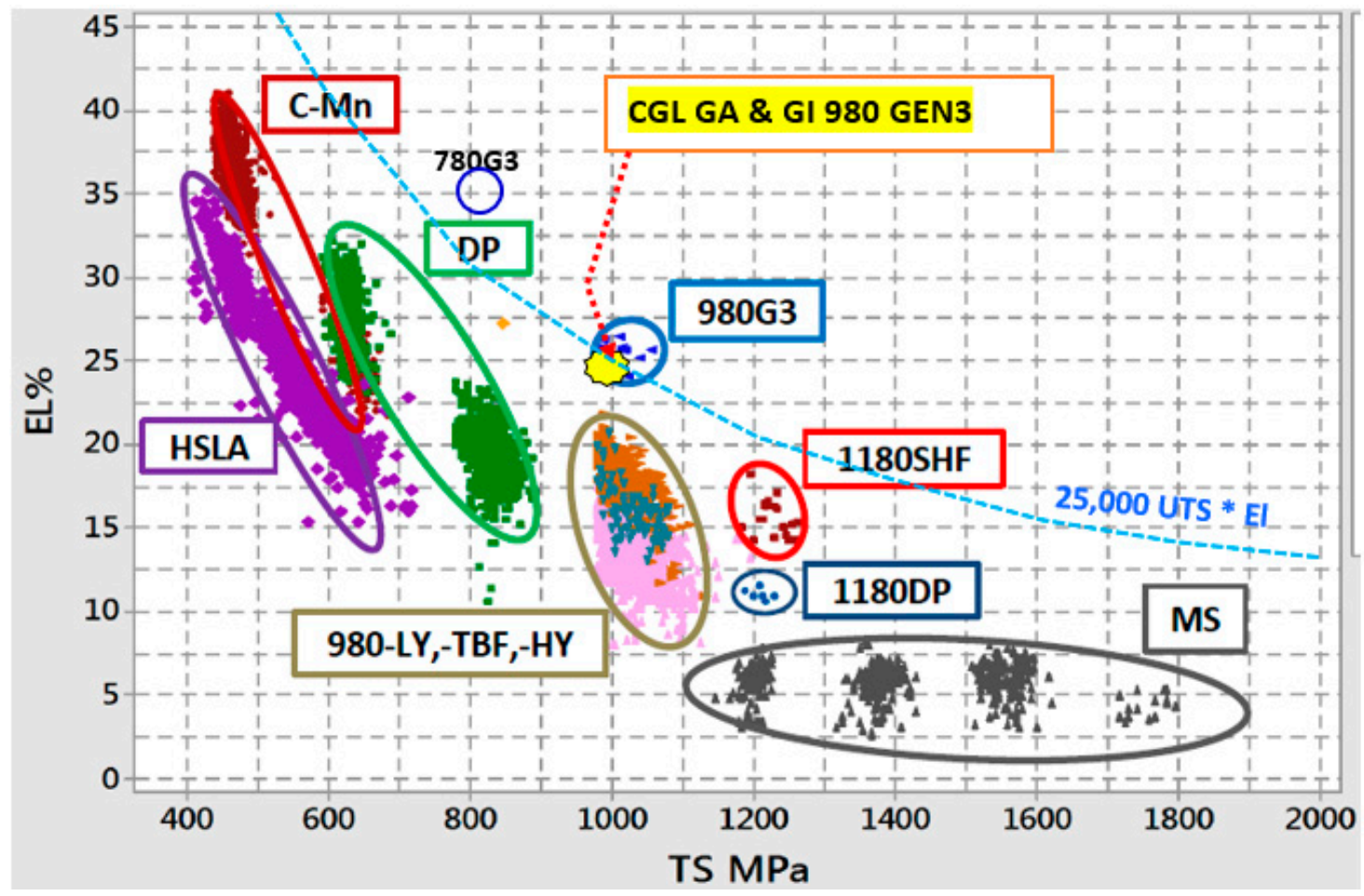

Figure 1. Different pathways to increase strength-ductility of AHSS [1].

\section{Rapid Austenitization}

According to Stahl Zentrum Stahl fur nachhaltige Mobilitat [2] hot stamped parts used in autos represent approximately $30 \%$ of all the body components. Mori et.al. [3], suggest that the use of high energy input during the process of hot stamping becomes an interesting proposition due to the effects of rapid heating on; (1) the transformation behavior of austenite; (2) oxidation behavior; (3) limited decarburization; (4) fine and/or coarser austenite grain sizes depending on reheating temperatures, holding times and heating rates; (5) localized non-uniform microstructures with substantial chemical heterogeneity; and (6) good hot workability. In summary, rapid heating and cooling during hot stamping seems to provide both a robust processing scheme and more cost effective approach than traditional reheating methods. Furthermore, the use of high input energy also opens the door to the potential development of new AHSS with higher strength and better total elongation.

Rapid heating technology is not new, the concept was initially developed to increase the mechanical properties of Armor plates for the US Army in 2010 [4]. Later on, the process was patented as a Micro-treatment of Iron-Based Alloy and Microstructure Resulting Therefrom [4]. It seems that by using rapid heating it is feasible to produce significant grain refinement of the decomposition products of austenite. There is substantial evidence that rapid hot forming based on high power and process integrated heating methods is an attractive proposition for the development of high strength steels with good formability [5-9]. Despite these claims, the state-of the-art in the development of AHSS steels using rapid heating seems to lack a better understanding on the effect of the starting microstructural condition and ultra-fast heating techniques. This is important because permits the better understanding of the formation and subsequent transformation behavior of austenite. To explore the effects of low and high input energy, starting microstructural condition, rapid cooling and resulting mechanical properties, the present study was conducted on a conventional 22MnB5 AHSS steel grade. 


\section{Experimental Procedure}

The samples used in this investigation were sectioned from the hot band condition of a commercial strip of $22 \mathrm{MnB} 5$ steel coiled around $660{ }^{\circ} \mathrm{C}$ having a final thickness of $2.5 \mathrm{~mm}$. The chemical composition of the steel is shown in Table 1.

Table 1. Chemical composition of 22MnB5 steel (Wt. \%).

\begin{tabular}{cccccccc}
\hline Element & $\mathbf{C}$ & Mn & Si & Ti & B & N & Cr \\
\hline Wt. \% & 0.234 & 1.51 & 0.124 & 0.025 & 0.0022 & 0.0048 & 0.011 \\
\hline \multicolumn{8}{c}{ Other elements: $\mathrm{Al}$, S, and P. }
\end{tabular}

\subsection{Microstructural Starting Condition}

Prior to any experimental testing, coupons of approximately $25.4 \mathrm{~cm} \times 25.4 \mathrm{~cm} \times 2.5 \mathrm{~mm}$ in size were sectioned from the hot band condition. The initial microstructural condition in the hot band was ferrite + pearlite. A number of coupons were subjected to subcritical spheroidization treatments $\left(675{ }^{\circ} \mathrm{C}\right.$ for $10 \mathrm{~h}$.). The two initial microstructural conditions are illustrated in Figure 2.

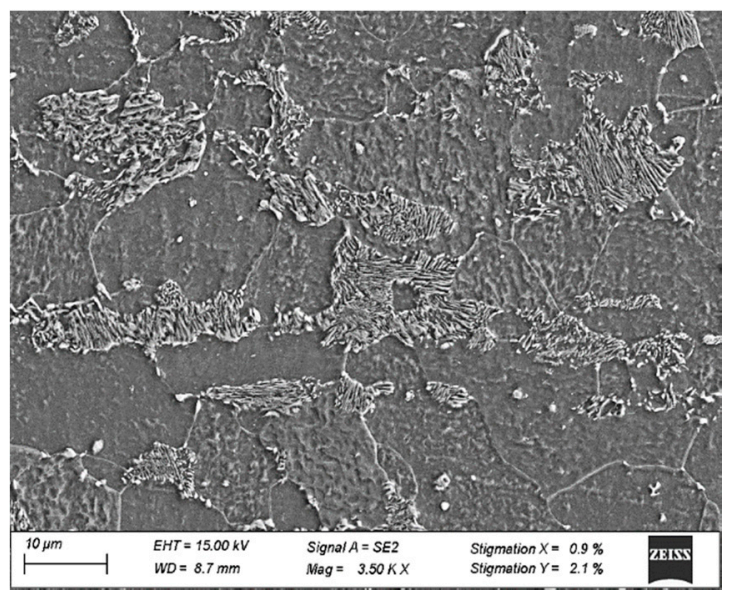

(a)

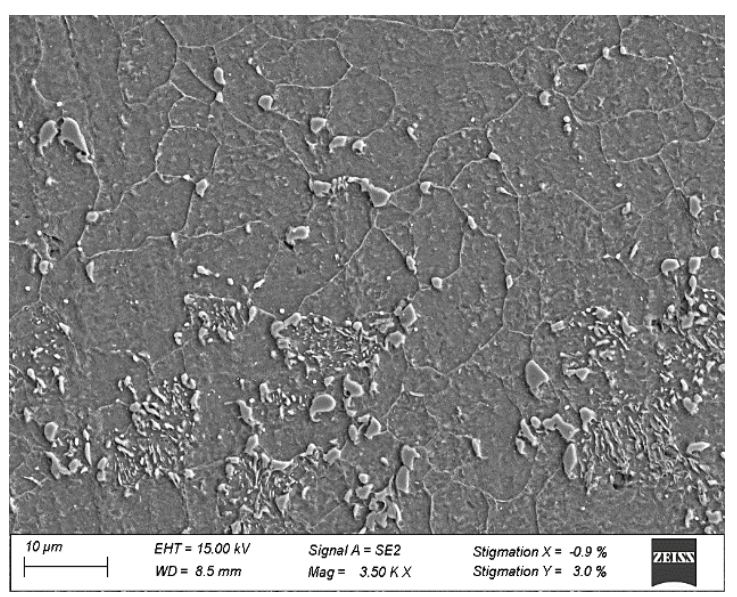

(b)

Figure 2. SEM micrographs of initial microstructures (a) ferrite + pearlite and (b) spheroidized.

\subsection{Heat Treatments}

Samples having the initial microstructural conditions were subjected to intercritical and supercritical treatments using a continuous annealing line (CAL) induction $30 \mathrm{~kW}$, 3-phase 480 $\mathrm{V}$ laboratory simulator with automated computer control for heating and cooling. This system is capable of reheating a sample $1.9 \mathrm{~cm}$ in thickness from RT (room temperature) to $1400^{\circ} \mathrm{C}$ in $2.5 \mathrm{~s}$ and capable of rapid controlled cooling at $300^{\circ} \mathrm{C} / \mathrm{s}$. The samples used in this study were $25.4 \mathrm{~cm}$ in length $\times 2.54 \mathrm{~cm}$ in width $\times 0.25 \mathrm{~cm}$ in thickness. A schematic of some of the heat treatments and cooling conditions used in this study are shown in Figure 3. The range of heat treatments studied included the temperatures of $732,756,772,792,845,895,1000$ and $1050^{\circ} \mathrm{C}$, respectively. 


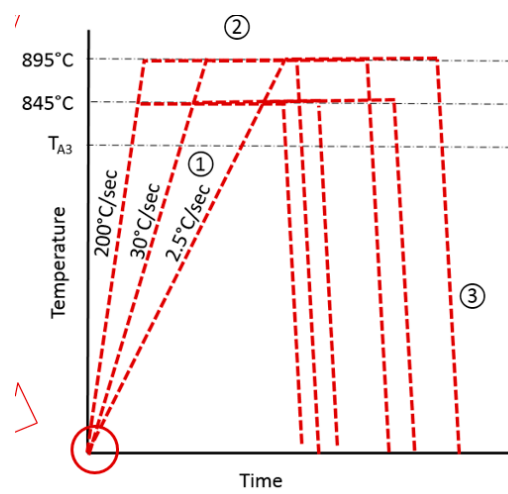

(1) Heating at $2.5,30$ and $200^{\circ} \mathrm{C} / \mathrm{sec}$

(2) Austenitization for 30 seconds at 845 and $895^{\circ} \mathrm{C}$

(3) Rapid cooling (ice brine water solution) - cooling rate of $300^{\circ} \mathrm{C} / \mathrm{sec}$

Figure 3. Schematic representation of the heat treatment cycles and photo of the laboratory CAL-induction simulator. $\mathrm{T}_{\mathrm{A} 3}$ is the transformation temperature.

\subsection{Optical, Scanning Electron Microscopy and EDS-EBSD Analysis}

The microstructural characterization of the samples in the starting and after heat treated were prepared for optical (OM), scanning electron microscopy (SEM) and EDS analysis by using standard metallographic procedures. Specimens for EBSD analysis were subjected to standard sample preparation followed by vibro-polishing in a VibroMet ${ }^{\circledR}$ polisher (Pace Technologies, Tucson, AZ, USA) for $3 \mathrm{~h}$ with $0.05 \mu \mathrm{m}$ nanometer alumina suspension.

The SEM analysis was conducted on a ZEISS Sigma 500 VP scanning electron microscope (ZEISS, Pittsburgh, PA, USA) equipped with Oxford Aztec X-EDS (Oxford Instruments, Abingdon, UK) with an operating voltage between $10 \mathrm{kV}$ and $20 \mathrm{kV}$. Electron Backscattered Diffraction (EBSD) and Image Quality (IQ) analyses were conducted on a FEI Scios FEG scanning electron microscope (University of Pittsburgh, Pittsburgh, PA, USA) equipped with an EBSD system. An accelerating voltage of $20 \mathrm{kV}$ with a beam current of $13 \mathrm{nA}$ were used. The details of dwelling time, tilt angle, distance, scanned area and step size and the details for the EBSD-IQ phase-microstructural analysis are also described elsewhere [10]. The EBSD-IQ approach was used to measure the volume fraction of the microconstituents formed during intercritical and supercritical annealing treatments. An area of 100 $\mu \mathrm{m} \times 100 \mu \mathrm{m}$ with a step size of $0.2 \mu \mathrm{m}$ was employed.

\subsection{Mechanical Testing}

Standard tensile coupons according to ASTM A8 were machined into sub-sized sheet tensile specimens with a gage length of $25 \mathrm{~mm}$. These tensile samples were sectioned and machined from the heat treated samples. The tensile coupons were tested at RT following the standard described in the ASTM specification mentioned before.

\section{Results and Discussion}

\subsection{Effect of Heating Rate on Transformation Temperatures $\left(A_{C 1}\right.$ and $\left.A_{C 3}\right)$ and the Nucleation of Austenite}

It is well-known that the transformation temperatures, $A_{C 1}$ and $A_{C 3}$, and the nucleation of austenite, are strongly affected by the heating rate. The effect of heating rates on the transformation temperatures can be calculated using a commercial thermodynamic software program J-MatPro (version 7 [11]), the results are presented in Figure 4. In this figure, according to the predictions of J-Mat Pro, it is shown that in order to obtain a fully homogeneous austenite transformation, the reheating temperature must be increased well above the $A_{C 3}$ temperature, especially at high heating rates. The formation of austenite is well-accepted to be a diffusion-controlled process, controlled by the slower diffusion process of interstitial elements, i.e., $\mathrm{C}$, in austenite when compared to the diffusion rates in ferrite. Therefore, for heat treatments in the temperature range of 845 and $895^{\circ} \mathrm{C}$, or even at higher temperatures, i.e., $1000^{\circ} \mathrm{C}$, it would not be expected that austenite will transform into $100 \%$ 
martensite during fast quenching. This view is independent of heating rates $\left(2.5,30\right.$ and $\left.200{ }^{\circ} \mathrm{C} / \mathrm{s}\right)$ prior to austenite transformation. For example, Figure 5 shows the EBSD-IQ results of ferrite-pearlite samples reheated at $1000^{\circ} \mathrm{C}$ using 2.5 and $200{ }^{\circ} \mathrm{C} / \mathrm{s}$ heating rates respectively, with a holding time of 30 $\mathrm{s}$ prior to rapid quenching. The results shown on this figure clearly support the theoretical predictions that a fully martensitic microstructure can't be obtained using slow or fast heating rates and short holding times at the supercritical temperatures. The resulting microstructure was a combination of martensite + bainite. This behavior can be explained by the effect of a heating rate and holding time on the nucleation and growth of austenite and the dissolution of $\mathrm{Fe}_{3} \mathrm{C}$ carbides. Several studies [12-14] have indicated that during rapid reheating the classical view of phase transformations will deviate markedly from those observed during equilibrium conditions. That is, the kinetics of transformation will have a different behavior. For example, faster heating rates favors nucleation of austenite, while slower heating rates leads to a significant growth of austenite. That is, slower heating rates permit $C$ diffusion through the austenite, enabling its growth. An additional effect is the holding time at a given temperature, fast heating rates and short holding times, promotes substantial local compositional differences in austenite.

TTA diagram

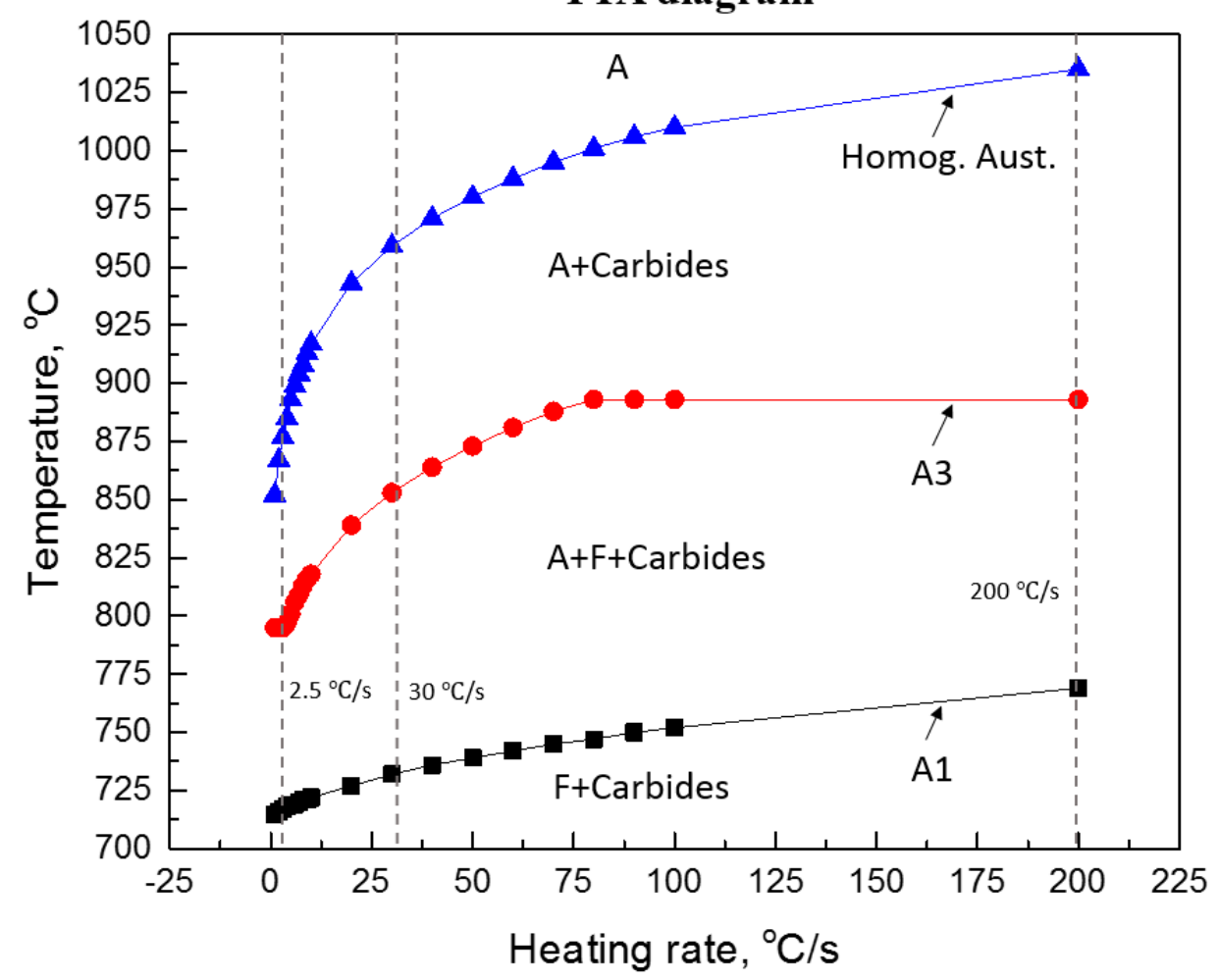

Figure 4. Shows the effect of heating rate on the transformation temperatures of 22MnB5 steel [11]. 


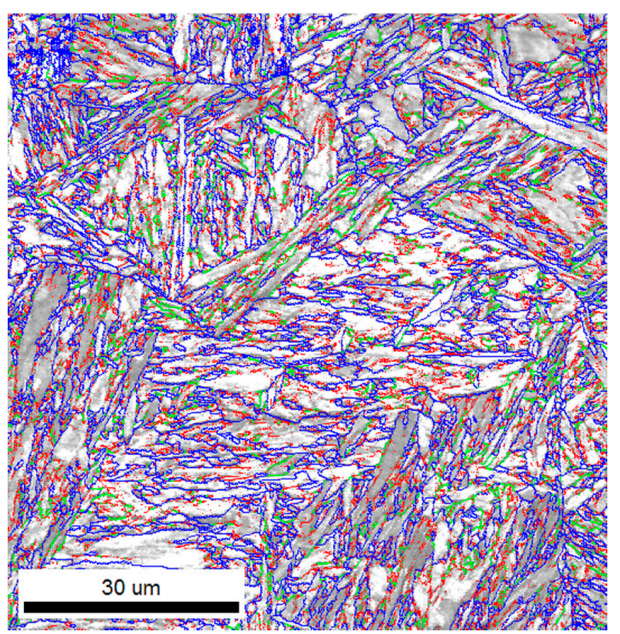

(a)

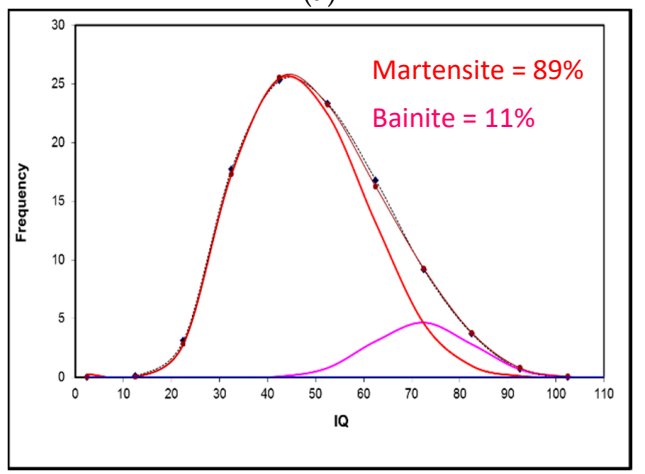

(c)

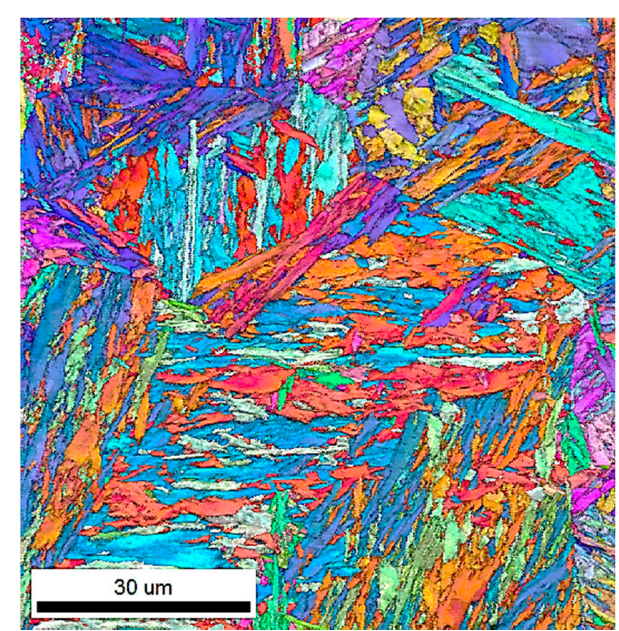

(b)

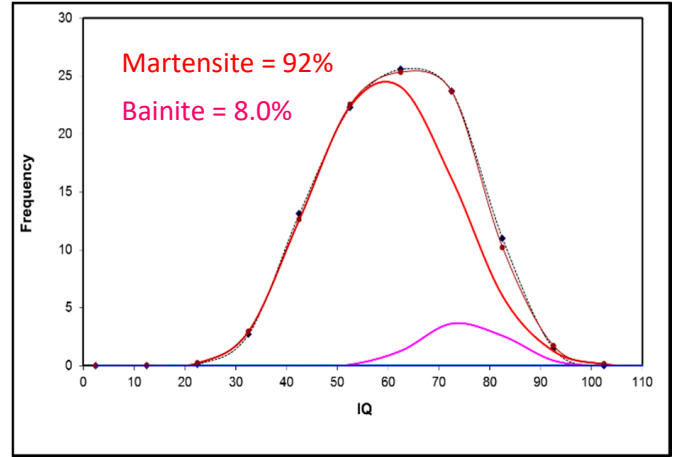

(d)

Figure 5. EBSD-IQ showing the microstructural balance of martensite and bainite after reheating a ferrite-pearlite microstructure at $1000{ }^{\circ} \mathrm{C}$ using heating rates of $2.5^{\circ} \mathrm{C} / \mathrm{s}$ and $200{ }^{\circ} \mathrm{C} / \mathrm{s}$ and WQ. (a) and (b) represent the reconstructed EBSD-IQ microstructure and inverse pole figure and grain boundary character distribution for the sample reheated at $2.5^{\circ} \mathrm{C} / \mathrm{s} \mathrm{WQ}$ sample. While (c) and (d) represent the EBSD-IQ analysis of the \% final microstructure for $2.5^{\circ} \mathrm{C} / \mathrm{s}$ and $200{ }^{\circ} \mathrm{C} / \mathrm{s}$ heating rates, respectively.

\subsection{Formation of Austenite during Intercritical Reheating (Annealing)}

The effect of the initial microstructure on the formation of austenite during intercritical reheating has been extensively studied. These studies provided a comprehensive view of the metallurgical reactions of austenite formation that take place during intercritical annealing; (1) nucleation and growth of austenite [15,16]; (2) the role of the initial microstructure [17]; (3) the incomplete dissolution of $\mathrm{Fe}_{3} \mathrm{C}$ carbides [18,19]; (4) the non-uniformity of carbon content in intercritical austenite [20]; (5) partitioning of interstitial and substitutional solutes between $\alpha$ and $\gamma$ phases [21]; and (6) the effect of heating rate [22].

Figure 6 shows the volume fraction of austenite formed during intercritical annealing (in the temperature range 732 to $792{ }^{\circ} \mathrm{C}$ ) as function of heating rate and initial microstructure at very short holding times, i.e., $30 \mathrm{~s}$. The results shown in this figure seem to indicate the influence of the initial microstructure and heating rate on the kinetics of transformation. That is, in a ferrite-pearlite microstructure, slower heating rate leads to higher nucleation and growth of austenite formation compared to faster heating rates for a given intercritical annealing temperature. When the initial microstructure is ferrite- $100 \%$ spheroidized $\mathrm{Fe}_{3} \mathrm{C}$ carbides, the formation of austenite doesn't have a similar dependence on the heating rate. This might be related to the fact that in a fully spheroidized microstructure, not all the $\mathrm{Fe}_{3} \mathrm{C}$ particles nucleate austenite. The $\mathrm{Fe}_{3} \mathrm{C}$ carbides located at the ferrite grain boundaries nucleate austenite preferentially, while those $\mathrm{Fe}_{3} \mathrm{C}$ carbides located in the matrix do not contribute to the nucleation of austenite. These carbides dissolve and the carbon contributes to the growth of austenite. In summary, the kinetics of austenite formation in a ferrite-pearlite microstructure 
can proceed in one or two stages depending on the heating rate. The results shown in Figure 6 also seem to support the view that the formation of austenite from an initial ferrite-spheroidized $\mathrm{Fe}_{3} \mathrm{C}$ microstructure tend to exhibit lower kinetics of austenite transformation compared to ferrite-pearlite or fully martensitic starting microstructures $[19,23,24]$.

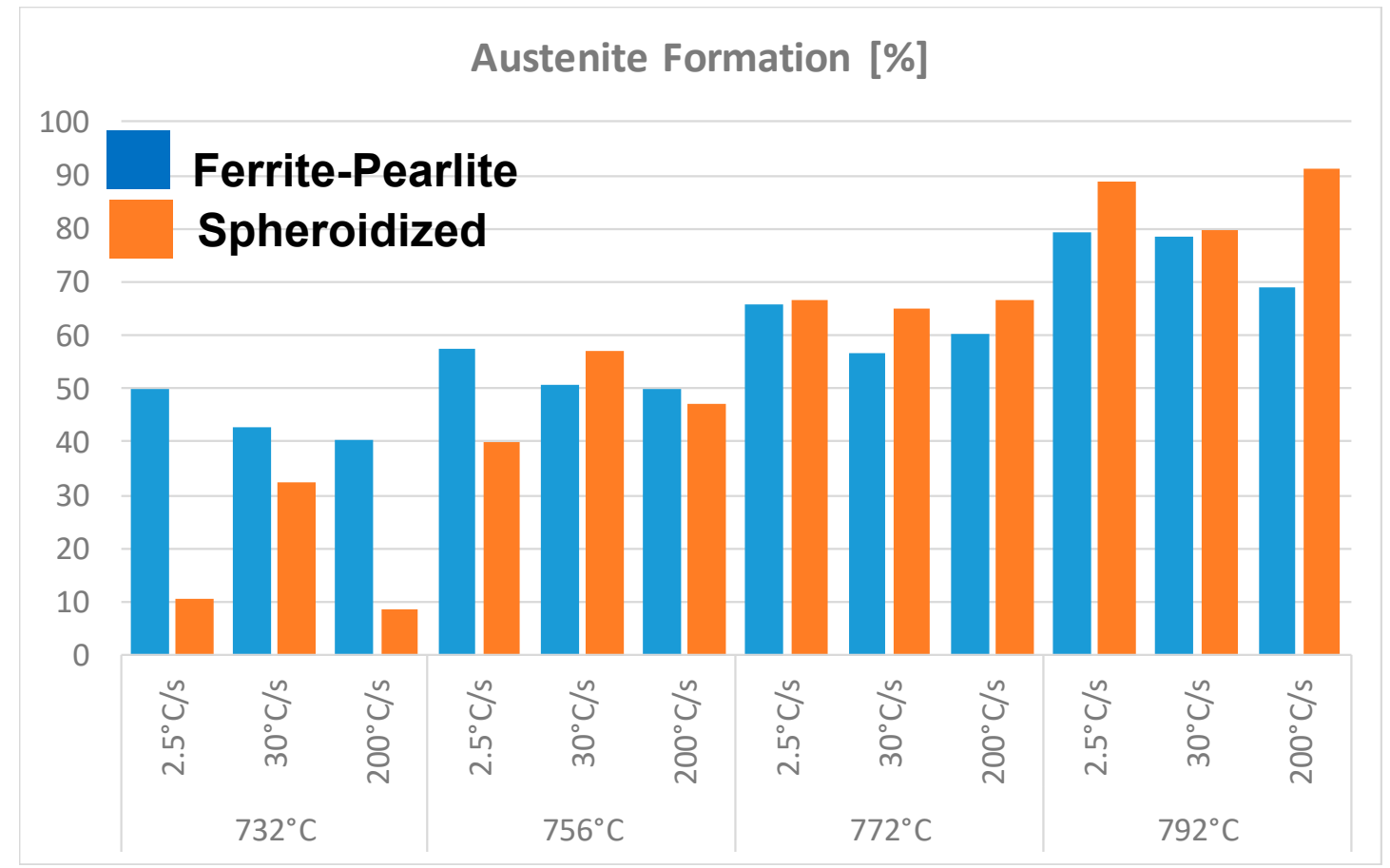

Figure 6. Formation of austenite during intercritical annealing as function of initial microstructural condition and heating rate.

It is well-accepted that the reheating temperature, holding time, and the effect of substitutional elements on the activity of carbon, controls the diffusion of carbon at the dissolving $\mathrm{Fe}_{3} \mathrm{C} / \gamma$ interphase, hence the growth rate of austenite can be described by the equation shown below [25].

$$
v=D \frac{d C}{d x}\left(\frac{1}{\Delta C^{\gamma \leftrightarrow \alpha}}+\frac{1}{\Delta C^{C} \leftrightarrow \alpha}\right)
$$

where $v$ is the velocity of the austenite phase boundary, $\mathrm{D}$ is the diffusion coefficient of $\mathrm{C}$ in austenite, $d C / d x$ is the carbon concentration in the austenite matrix, $\Delta C^{\gamma \leftrightarrow \alpha}$ and $\Delta C^{C \leftrightarrow \gamma}$ are the differences in carbon concentration between austenite and ferrite and carbide and austenite, respectively. Mn segregation at the $\mathrm{Fe}_{3} \mathrm{C} / \gamma$ interphase will decrease the diffusion of $\mathrm{C}$ through the austenite, hence decreasing the growth rate of austenite. The segregation of $\mathrm{Mn}$ in the lamellae pearlite and at the $\mathrm{Fe}_{3} \mathrm{C} / \alpha$ interphase, i.e., spheroidized carbides is shown in Figure 7. This segregation affects the dissolution of $\mathrm{Fe}_{3} \mathrm{C}$ and hence the kinetics of carbon diffusion in austenite during intercritical and supercritical heat treatments. 

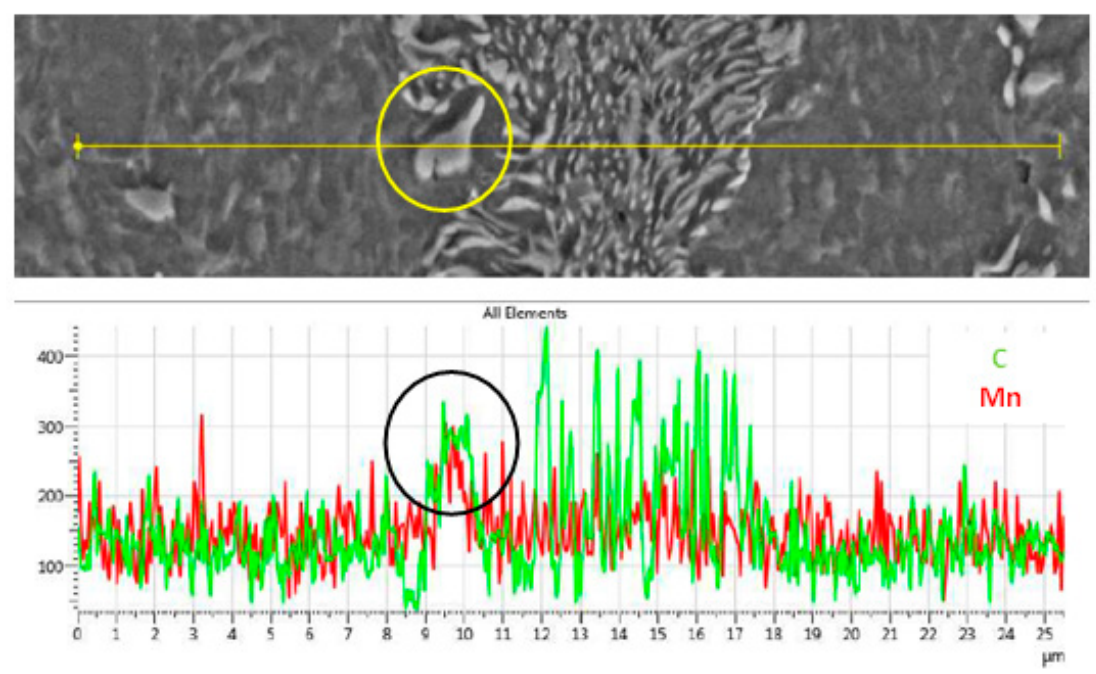

Figure 7. SEM-EDS line scan showing the segregation of $\mathrm{C}$ and $\mathrm{Mn}$ in the pearlite and $\mathrm{Fe}_{3} \mathrm{C}$ carbides.

\subsection{Formation of Austenite during Supercritical Reheating}

Prior to studying the effect of reheating temperatures, heating rates and initial microstructure on the formation of austenite during supercritical annealing, the prior austenite grain size (PAGS) was determined. The results of the PAGS from different initial microstructural conditions and reheated at $845^{\circ} \mathrm{C}$ and $895^{\circ} \mathrm{C}$, held $30 \mathrm{~s}$ at temperature and rapidly quenched in an ice brine solution are shown in Figure 8 . The results show that the heating rate doesn't have a strong influence on the average PAGS. Meanwhile, as expected, the average PAGS value increases slightly with the reheating temperature (see table in Figure 8). The scale in the micros is $(50 \mu \mathrm{m})$.

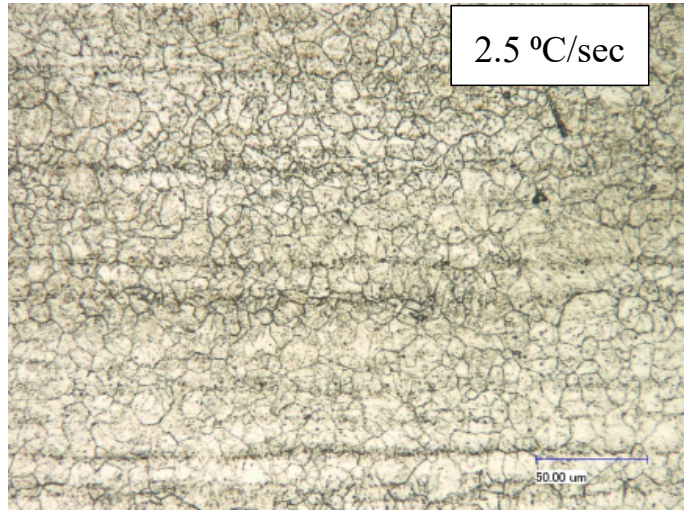

(a)

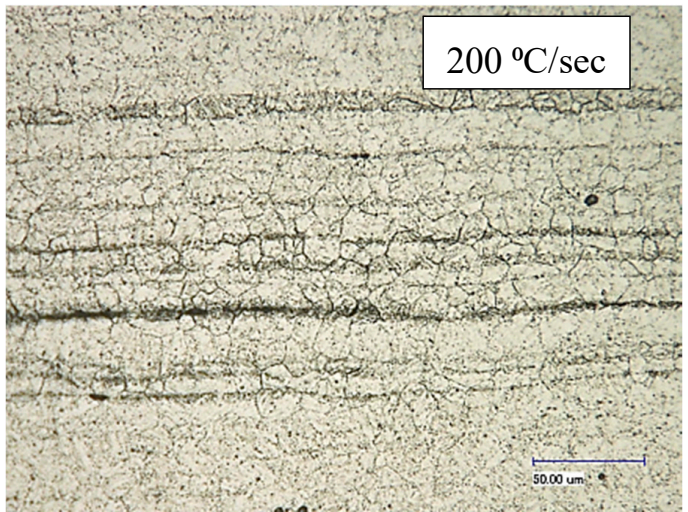

(b)

\begin{tabular}{|r|c|c|c|c|}
\multicolumn{2}{|c|}{$\begin{array}{c}\text { Initial Condition and } \\
\text { Reheating Temperature }\end{array}$} & \multicolumn{3}{|c|}{ Heating Rate } \\
\hline \multirow{2}{*}{$845^{\circ} \mathrm{C}$} & Ferrite-Pearlite & $11.30 \pm 2.4$ & $10.96 \pm 2.1$ & $200^{\circ} \mathrm{C} / \mathrm{s}$ \\
\hline \multirow{2}{*}{$895^{\circ} \mathrm{C}$} & Spheroidized & $11.86 \pm 1.7$ & $9.90 \pm 2.8$ & $8.76 \pm 2.3$ \\
\cline { 2 - 5 } & Ferrite-Pearlite & $17.87 \pm 5.3$ & $16.61 \pm 5.6$ & $14.98 \pm 3.9$ \\
\hline & Spheroidized & $16.98 \pm 4.6$ & $13.84 \pm 3.0$ & $15.13 \pm 4.9$ \\
\hline
\end{tabular}

(c)

Figure 8. Average PAGS in $\mu \mathrm{m}$ as function of heating rate, reheating temperature and initial microstructural condition; (a) OM of PAGS from $845^{\circ} \mathrm{C}$ and (b) $895^{\circ} \mathrm{C}$. While (c) shows the PAGS values.

The decomposition products of austenite as function of initial microstructure, reheating temperature, heating rate and $30 \mathrm{~s}$ holding time prior to fast quenching are shown in Figure 9. The microstructural balance was obtained using the EBSD-IQ method described by Wu et al. [10], this 
method was also used in Figure 5. The results shown in Figure 9 indicate that the microstructures consisted of a mixture of martensite + bainite + undissolved $\mathrm{Fe}_{3} \mathrm{C}$ carbides and small amount of martensite-austenite (MA) microconstituents. As expected, the amount of undissolved carbides and the MA seems to decrease as the reheating temperature increases. This is supported by the theoretical prediction (Figure 4) and the results presented in Figure 5. It is important to indicate that 100\% martensite was not observed in any of the samples observed in this study.

\begin{tabular}{|c|c|c|c|c|c|}
\hline \multirow{2}{*}{ Temperature $\left({ }^{\circ} \mathrm{C}\right)$} & $\begin{array}{c}\text { Initial } \\
\text { Microstructure }\end{array}$ & Heating Rate & Martensite (\%) & Bainite (\%) & $\mathrm{Fe}_{3} \mathrm{C}+\mathrm{MA}(\%)$ \\
\hline \multirow{2}{*}{845} & Ferrite-Pearlite & $2.5^{\circ} \mathrm{C} / \mathrm{s}$ & 70.5 & 24 & 5.5 \\
\hline & Spheroidized & $2.5^{\circ} \mathrm{C} / \mathrm{s}$ & 79.2 & 19.25 & 1.55 \\
\hline \multirow{2}{*}{845} & Ferrite-Pearlite & $30^{\circ} \mathrm{C} / \mathrm{s}$ & 70.1 & 26.4 & 3.5 \\
\hline & Spheroidized & $30{ }^{\circ} \mathrm{C} / \mathrm{s}$ & 75 & 22.9 & 2.1 \\
\hline \multirow{2}{*}{845} & Ferrite-Pearlite & $200^{\circ} \mathrm{C} / \mathrm{s}$ & 69.4 & 27.6 & 3.0 \\
\hline \multirow{2}{*}{895} & Spheroidized & $200^{\circ} \mathrm{C} / \mathrm{s}$ & 71.7 & 25.8 & 2.5 \\
\hline \multirow{2}{*}{895} & Ferrite-Pearlite & $2.5^{\circ} \mathrm{C} / \mathrm{s}$ & 68.4 & 27.8 & 3.8 \\
\hline & Spheroidized & $2.5^{\circ} \mathrm{C} / \mathrm{s}$ & 73 & 25 & 2 \\
\hline \multirow{2}{*}{895} & Ferrite-Pearlite & $30^{\circ} \mathrm{C} / \mathrm{s}$ & 70.5 & 26.6 & 2.9 \\
\hline & Spheroidized & $30^{\circ} \mathrm{C} / \mathrm{s}$ & 71 & 27.29 & 1.71 \\
\hline
\end{tabular}

(a)

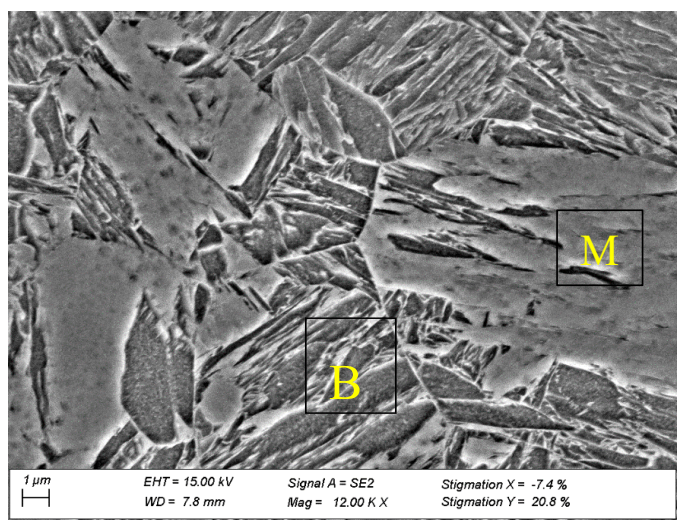

(b)

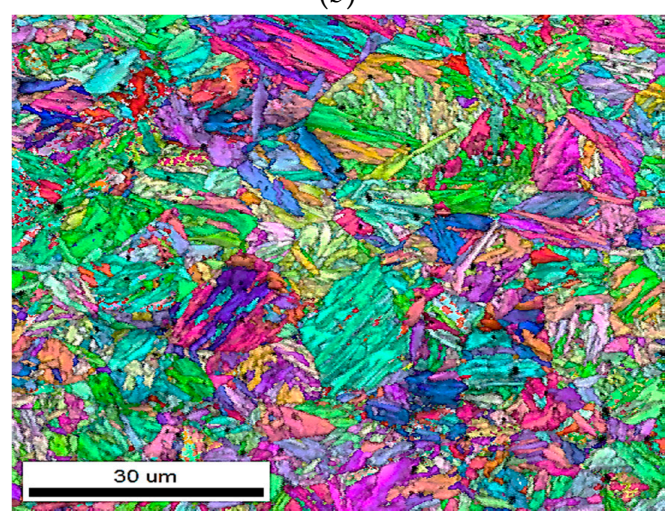

(d)

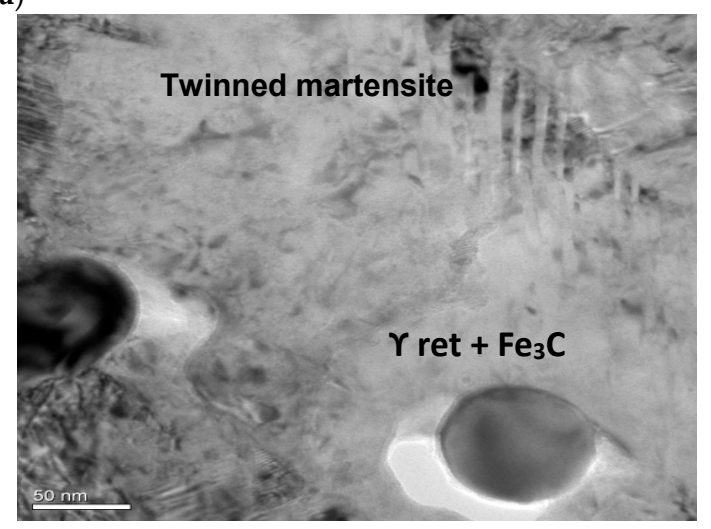

(c)

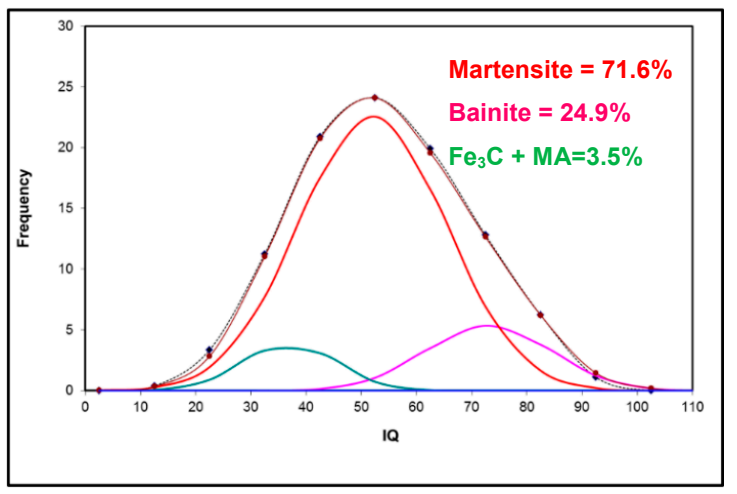

(e)

Figure 9. SEM-TEM and EBSD-IQ of WQ microstructure after reheating at $895{ }^{\circ} \mathrm{C}$ at a heating rate of $200{ }^{\circ} \mathrm{C} / \mathrm{s}$ and fast quenched. Initial microstructure fully spheroidized; (a) Table of microstrucrual components based on the EBSD-IQ technique; (b) SEM micrograph showing martensite and bainite; (c) TEM micrograph showing undissolved $\mathrm{Fe}_{3} \mathrm{C}$ carbides and retained $\gamma$ at the carbide/matrix interface; (d) shows the inverse pole figure (IPF) and grain boundary character distribution, and (e) are the results from the EBSD-IQ analysis showing the percent of microstructural components. 


\subsection{Mechanical Properties}

The tensile properties of a selected number of fully processed samples (ferrite-pearlite) from Figure 9 were tested and the resulting mechanical properties were evaluated, see Figure 10. As expected, the flow stress was continuous for all the samples tested. A comparison of the UTS shows that the samples reheated at $845^{\circ} \mathrm{C}$ with a heating rate of $2.5^{\circ} \mathrm{C} / \mathrm{s}$ and those reheated using $30{ }^{\circ} \mathrm{C} / \mathrm{s}$ exhibited a slightest difference in UTS value $1591 \mathrm{MPa}$ versus $1648 \mathrm{MPa}$, respectively. This behavior can be explained by the increased amount of martensite + bainite and less $\mathrm{Fe}_{3} \mathrm{C}+\mathrm{MA}$ in the overall microstructure observed in the samples after reheating at $30^{\circ} \mathrm{C} / \mathrm{s}$ compared to those reheated using $2.5^{\circ} \mathrm{C} / \mathrm{s}$. Interestingly reheating at higher supercritical temperatures, i.e., $1000^{\circ} \mathrm{C}$, did not increase the mechanical properties, as can be seen in Table 2. In this table, the average mechanical properties of the ferrite-pearlite and spheroidized samples reheated at $845^{\circ} \mathrm{C}$ and WQ (water quenched) are also shown for comparison purposes. The YS and UTS for both starting conditions were very similar, the total elongation of the spheroidized samples was slightly lower compared to that of the ferrite-pearlite samples. The explanation for this behavior could be that the presence of some undissolved $\mathrm{Fe}_{3} \mathrm{C}$ carbides acted as nucleation sites for the onset of the diffusive necking. Reheating at higher supercritical temperatures and fast cooling produces an increase in the percent of martensite, lower percent of bainite and the presence of $\mathrm{Fe}_{3} \mathrm{C}+\mathrm{MA}$ was not observed, compare Figures 5 and 9. These results are in strong agreement with the common knowledge that optimum microstructural combinations of martensite + bainite are stronger than 100\% martensite.

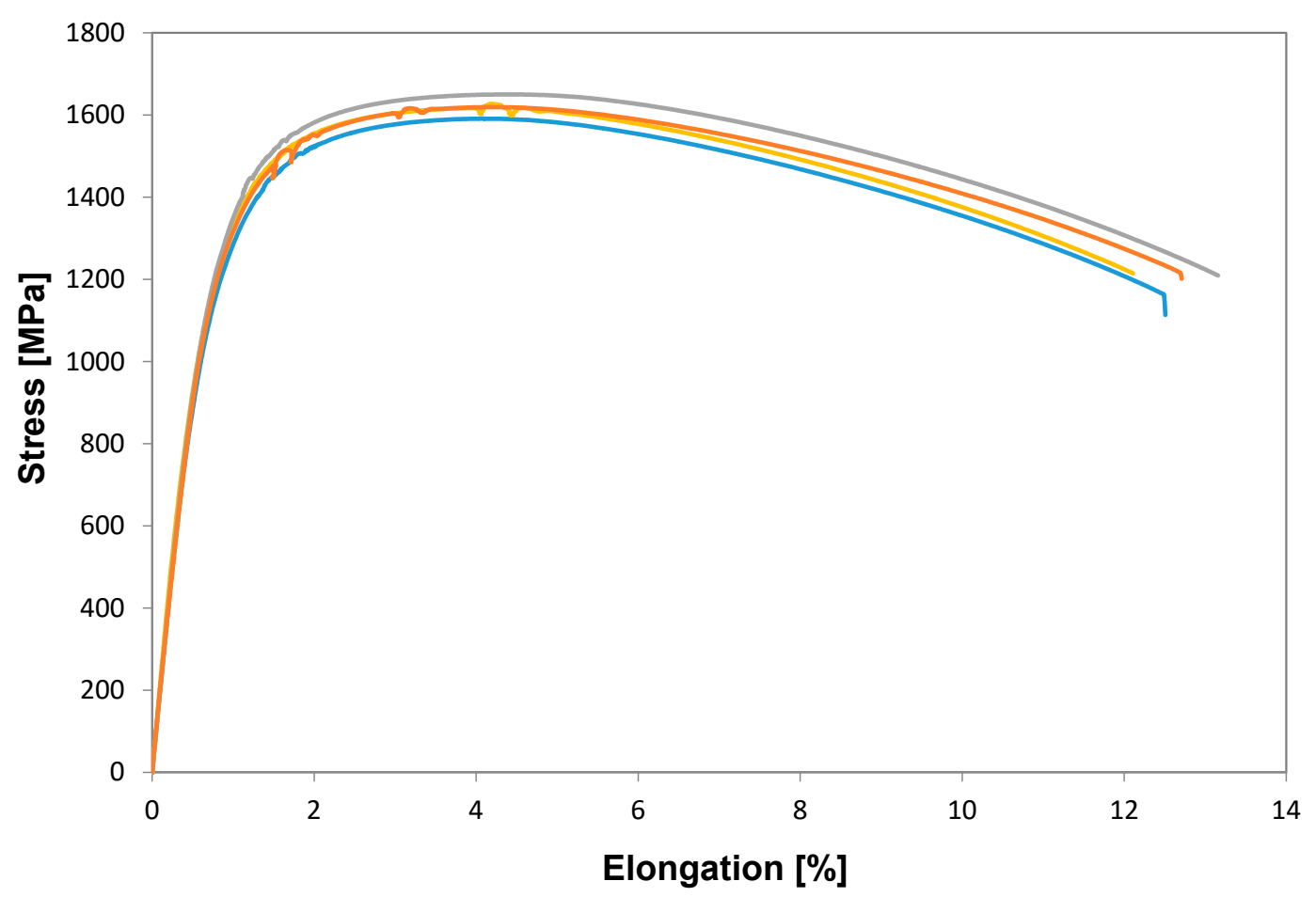

Figure 10. Flow behavior of ferrite-pearlite samples reheated at 845 and $895{ }^{\circ} \mathrm{C}$ using 2.5 and $30{ }^{\circ} \mathrm{C} / \mathrm{s}$ respectively followed by rapid cooling $\left(300^{\circ} \mathrm{C} / \mathrm{s}\right)$. All the results shown on this figure correspond to samples with an initial ferrite-pearlite microstructure. 
Table 2. Average tensile properties of samples after reheating and WQ.

\begin{tabular}{|c|c|c|c|c|c|}
\hline Temp. $\left({ }^{\circ} \mathrm{C}\right)$ & Initial Microstructure & H.R. $\left({ }^{\circ} \mathrm{C} / \mathrm{s}\right)$ & UTS (MPa) & YS (MPa) & Elongation (\%) \\
\hline \multirow{3}{*}{845} & \multirow{3}{*}{ Ferrite-Pearlite } & 2.5 & 1591.3 & 1116.5 & 12.8 \\
\hline & & 30 & 1648.2 & 1120.2 & 13.5 \\
\hline & & 200 & 1620.0 & 1117.7 & 11.4 \\
\hline \multirow{3}{*}{845} & \multirow{3}{*}{ Spheroidized } & 2.5 & 1575.2 & 1106.1 & 11.9 \\
\hline & & 30 & 1637.3 & 1099.1 & 11.4 \\
\hline & & 200 & 1600.4 & 1115.7 & 10.6 \\
\hline \multirow{3}{*}{1050} & \multirow{3}{*}{ Ferrite-Pearlite } & 2.5 & 1566.0 & 1126.4 & 10.7 \\
\hline & & 30 & 1575.2 & 1072.2 & 10.4 \\
\hline & & 200 & 1606.7 & 1152.3 & 10.0 \\
\hline
\end{tabular}

\section{Conclusions}

The results of this study clearly show the effect of the heating rate and initial microstructure on the nucleation and growth of austenite during intercritical and supercritical temperature. In ferrite-pearlite microstructures, slower heating rates, nucleation and growth reactions are preferred. Fast heating rates have a strong influence on the carbide dissolution during intercritical and supercritical annealing treatments. The transformation behavior of austenite after supercritical annealing at small $\Delta T\left(T-T_{A c 3}\right)$ and fast cooling rates always resulted in a multi-phase complex microstructure. At higher $\Delta T^{\prime}$ s a duplex microstructure with more martensite and less bainite was observed. The PAGS was not strongly influenced by fast heating rates and short holding times. The best combination of mechanical properties was obtained at small $\Delta T$ when the balance of martensite and bainite was optimum.

Author Contributions: All the authors contributed to this work. J.P.P. obtained his M.Sc. degree with this work; R.L.-M. conducted the EBSD-IQ and SEM analysis; O.G.-R. performed the mechanical testing; and C.I.G. was the academic advisor and wrote the manuscript.

Acknowledgments: The authors would like to thank TERNIUM-MEXICO for providing the commercial samples used on this study and the financial support. Also the authors would like to thank the members of the Ferrous Physical Metallurgy-MEMS Department at the University of Pittsburgh for their support.

Conflicts of Interest: The authors have not conflict of interest.

\section{References}

1. Goodwin, F.E.; Silva, E.A. Current Priorities in Developing, Forming and Joining of Advanced Galvanized Sheet Steels. In Proceedings of the GALVATECH 2017: 11th International Conference on Zinc and Zinc Alloy Coated Steel Sheet, Tokyo, Japan, 12-16 November 2017.

2. Stahl Zentrum Stahl fur Nachhaltige Mobilitat. Available online: http:/www.stahl-online.de/index.php/ themen/stahanwendung/mobilitaet/ (accessed on 20 November 2018).

3. Mori, K.; Maeno, T.; Yamada, H.; Matsumoto, H. 1-Shot hot stamping of ultra-high strength steel parts consisting of resistance heating, forming, shearing and die quenching. Int. J. Mach. Tools Manuf. 2015, 89, 124-131. [CrossRef]

4. Cola, G.M. Flash Bainite: Room Temp Stamping 1500 to 1800 MPa Structural and Energy Absorbing Components to $<2 \mathrm{~T}$ Bend Radii and the Coil-Coil Production Equipment. In Proceedings of the AISTech 2018, Philadelphia, PA, USA, 7 May 2018; pp. 2731-2743.

5. Cola, G.M. Microtretament of Iron-Bases Alloy, Apparatur and Method Therefor, and Microstructure Resulting Therefrom. USA Patent 2010/0163140 A1, 1 July 2010.

6. Lolla, T.; Alexandrov, B.; Babu, S.; Cola, G. Towards Understanding the Microstructure Developments during Flash Heating and Cooling of Steels; The Ohio State University: Columbus, OH, USA, 2009. 
7. HolzweiBig, M.J.; Lackmann, J.; Konrad, S.; Schaper, M.; Niendorf, T. Influence of short austenitization treatments on the mechanical properties of low alloy steels for hot forming applications. Metall. Mater. Trans. A 2015, 46, 3199-3207. [CrossRef]

8. Niesse, M.; Lackmann, J.; Frost, G.; Konrad, S.; Lambers, H.G. Warmformlinie und Verfahren zur Herstellung von Warmumgeformten Blechprodukten. Patent DE102014101539A1, 13 August 2015.

9. Kollec, R.; Veit, R.; Merklein, M.; Lechler, J.; Geiger, M. Investigation on induction heating for hot stamping of boron alloyed steels. CIRP Ann.-Manuf. Technol. 2009, 58, 275-278. [CrossRef]

10. Wu, J.; Wray, P.; Garcia, C.I.; Hua, M.; DeArdo, A.J. Image Quality Analysis: A new method of characterizing microstructures. ISIJ Int. 2005, 45, 254-262. [CrossRef]

11. Garcia, C.I. JMatPro Software V7; Sente Software Ltd.: Guildford, UK.

12. Lobbe, C.; Becker, C.; Tekkaya, A.E. Warm bending of microalloyed high-strength steel by local induction heating. In Forming Technology Forum; University of Twente: Enschede, The Netherlands, 2014; pp. 99-104.

13. Allwood, J.M.; Childs, T.H.C.; Clare, A.T.; De Silva, A.K.M.; Dhokia, V.; Hutchings, I.M.; Leach, R.K.; Leal-Ayala, D.R.; Lowth, S.; Majewski, C.E. Manufacturing at double the speed. J. Mater. Process Technol. 2016, 229, 729-757. [CrossRef]

14. Lobbe, C.; Hering, O.; Hiegemann, L.; Tekkaya, A.E. Setting Mechanical Properties of High Strength Steels for Rapid Hot Forming Process. Materials 2016, 9, 229. [CrossRef]

15. Roberts, G.A.; Mehl, R.F. The mechanism and the Rate of Austenite from Ferrite-Cementite Aggregates. AMS Trans. 1943, 31, 613-649.

16. Molinder, G. A Quantitative Study of the Formation of Austenite and the Solution of Cementite at Different Austenitizing Temperatures for a 1.27 wt \% Carbon Steel. Acta Metall. 1956, 4, 565-571. [CrossRef]

17. Judd, R.R.; Paxton, H.W. Kinetics of Austenite Formation from a Spheroidized Ferrite-Carbide Aggregate. Trans. TMS-AIME 1968, 242, 206-215.

18. Speich, G.R.; Szirmae, A. Formation of Austenite from Ferrite and Ferrite-Carbide Aggregate. Trans. TMS-AIME 1969, 245, 1063-1074.

19. Garcia, C.I.; DeArdo, A.J. Formation of Austenite in 1.5 Pct. Mn Steels. Metall. Trans. A Phys. Metall. Mater. Sci. 1981, 12, 521-530. [CrossRef]

20. Speich, G.; Demarest, V.; Miller, R. Formation of austenite during intercritical annealing of dual-phase steels. Metall. Mater. Trans. A 1981, 12, 1419-1428. [CrossRef]

21. Azizi-Alizamini, H.; Militzer, M.; Poole, W.J. Austenite Formation in Plain Low-Carbon Steels. Metall. Mater. Trans. A: Phys. Metall. Mater. Sci. 2011, 42, 1544-1557. [CrossRef]

22. Dyachenko, S.S. The Austenite Formation in Fe-C Alloys. Metallurgiya 1982, 128.

23. Golovanenko, S.A.; Fonstein, N.M. Dual-Phase Low Alloyed Steels. Metallurgiya 1986, 206.

24. Law, N.C.; Edmonds, D.V. The Formation of Austenite in a Low-Alloy Steel. Metall. Mater. Trans. A 1980, 11, 33-46. [CrossRef]

25. Wycliffe, P.; Purdy, G.R.; Embury, J.D. Austenite Growth in the Intercritical Annealing of Ternary and Quaternary Dual-Phase Steels. In Fundamentals of Dual-Phase Steels, Proceedings of the Symposium at the 110th AIME Annual Meeting, Chicago, IL, USA, 23-24 February 1981; Metallurgical Society of AIME: Warrendale, PA, USA, 1981; pp. 59-83.

(C) 2019 by the authors. Licensee MDPI, Basel, Switzerland. This article is an open access article distributed under the terms and conditions of the Creative Commons Attribution (CC BY) license (http://creativecommons.org/licenses/by/4.0/). 